\title{
Shared Education in contested spaces: How collaborative networks improve communities and schools
}

\author{
Gavin Duffy ${ }^{1} \cdot$ Tony Gallagher ${ }^{1}$
}

Published online: 13 August 2016

(C) The Author(s) 2016. This article is published with open access at Springerlink.com

\begin{abstract}
Societies which suffer from ethnic and political divisions are often characterised by patterns of social and institutional separation, and sometimes these divisions remain even after political conflict has ended. This has occurred in Northern Ireland where there is, and remains, a long-standing pattern of parallel institutions and services for the different communities. A socially significant example lies in the education system where a parallel system of Catholic and Protestant schools has been in place since the establishment of a national school system in the 1830s. During the years of political violence in Northern Ireland a variety of educational interventions were implemented to promote reconciliation, but most of them failed to create any systemic change. This paper describes a postconflict educational initiative known as Shared Education which aims to promote social cohesion and school improvement by encouraging sustained and regular shared learning between students and broader collaboration between teachers and school leaders from different schools. The paper examines the background to work on Shared Education, describes a 'sharing continuum' which emerged as an evaluation and policy tool from this work and considers evidence from a case study of a Shared Education school partnership in a divided city in Northern Ireland. The paper will conclude by highlighting some of the significant social and policy impact of the Shared Education work.
\end{abstract}

Keywords Contested spaces - Divided societies - Shared Education · School collaboration

Gavin Duffy

g.duffy@qub.ac.uk

1 School of Education, Queen's University Belfast, 20 College Green, Belfast BT7 1LN, UK 


$\begin{array}{ll}\text { Abbreviations } \\ \text { CCEA } & \text { Council for the Curriculum, Examinations and Assessment } \\ \text { CCMS } & \text { Catholic Council for Maintained Schools } \\ \text { DENI } & \text { Department of Education for Northern Ireland } \\ \text { IME } & \text { Irish Medium Education } \\ \text { LLW } & \text { Learning for life and work } \\ \text { OFMDFM } & \text { Office of the First and Deputy First Minister } \\ \text { PDMU } & \text { Personal Development and Mutual Understanding } \\ \text { PSNI } & \text { Police Service Northern Ireland } \\ \text { SEP } & \text { Sharing Education Program } \\ \text { SESP } & \text { Shared Education Signature Project }\end{array}$

\section{Introduction}

The idea of the nation-state included an assumption that the 'imagined community' (Anderson 1991) of the nation encompassed a culturally distinct community, with its own history and traditions. Nation-states are in fact, heterogeneous, due to the historical mismatch between borders and peoples, or economic or other forms of migration: the 'imagined community' of the nation-state typically reflects the 'imagining' of the dominant community. When the relationship between communities in these contexts are characterised by asymmetric power then the interfaces between the communities can create 'contested spaces'. These 'contested spaces' have a number of functions: they demarcate communities and become places where conflict can break out as people defend ethnic boundaries, and they can also act as a means for maintaining separate identities, particularly for minority communities (Minority Rights Group 1994). Contested spaces need not be geographically coterminous, but can be represented by institutional boundaries which keep people apart by organising them into separate areas of service provision, such as cultural activities or schools. They can be malign, as sites of conflict, or benign, as lines of demarcation. However, even when they are benign they can act to create silos which, by maintaining intra-group integrity and intergroup separation, render it difficult to change or improve intergroup relations: Roche (2009: 36) defines this circumstance as 'bounded contentment', the risk of which is possibly most pronounced when the contested spaces are created by institutional boundaries. There are numerous 'contested spaces' in Northern Ireland, only some of which are contexts of direct conflict between the Protestant and Catholic communities (Leonard 2006; Morrissey and Gaffikin 2006; Graham 2006; Gaffikin et al. 2008; Duffy and Gallagher 2015). In most cases the 'contested spaces' evoke 'bounded contentment' as they do little to challenge the verities of religious division or provide society with effective means of dealing with diversity.

Northern Ireland is a society divided by religious, national and political identities. These divisions are reflected in education as there are parallel school systems for Protestant and Catholic communities, tempered by the presence of a small religiously integrated sector of schools. School uniforms act as visible 
markers of difference, making it relatively easy to identify a student's religion simply by recognising the school uniform. Separate schools act as institutional barriers between young people and, as such, provide an example of 'contested space'. At the outbreak of political violence at the end of the 1960s, many argued that separate denominational schools had reinforced the divisions in society. Others argued that the cause of divisions lay elsewhere, particularly in the unequal relationship between the Protestant majority and Catholic minority (Heskin 1980; Fraser 1974; Gallagher 2004). Despite extensive debate there was little consensus on this issue and educators put in place a range of interventions, charged as they were with preparing young people to live and work in a divided society.

After a quarter century of political violence, followed by almost two decades of relative peace, over the past 10 years a new education initiative has developed aimed at changing the 'contested space' between separate schools into 'shared space'. 'Shared Education' sees schools as part of a network, rather than as a system of autonomous units, and seeks to encourage positive interdependence between schools by promoting systemic collaboration in which students and teachers move between schools to take and give classes. In this way, Shared Education seeks to establish a different pattern of relationships between schools, students, teachers and parents so that separate schools start to connect communities, rather than act as institutional barriers between them.

The paper has three main sections. First we examine previous educational initiatives aimed at promoting reconciliation and tolerance, before outlining the development of the Shared Education model. Second, we discuss the theoretical framework which underpins Shared Education and introduce a 'sharing continuum'-a policy tool we developed to support the mainstreaming of Shared Education. And third, in order to provide an illustration of the work undertaken through Shared Education, we provide an in-depth case study of one Shared Education initiative in a largely segregated urban area.

\section{Separate education in Northern Ireland}

At the formation of Northern Ireland in the early 1920s there were parallel school systems for Protestants and Catholics, a situation which largely remains intact. There is currently a complex nomenclature of schools, but essentially there are three broad types:

- 'Catholic' schools are owned and managed by the Catholic Church, and serve mainly Catholic students and teachers.

- The Protestant Churches transferred their schools to local authority control in the 1930s, but only after extracting concessions from the government which allowed them to retain a significant level of influence on the schools through governance, teacher recruitment and the curriculum. In practice, most of the students and teachers in these schools are Protestant, and so we refer to them here as 'Protestant' schools. 
- In 1981 the first 'integrated' school opened on the basis that they were inclusive and welcomed all students, regardless of gender, religion or academic status. The integrated sector currently comprises $7 \%$ of the total student population.

Northern Ireland continues to operate a system of academic selection, with academically selective grammar schools and non-selective secondary schools for students aged 11-18 years. Most grammar schools enjoy a higher degree of financial and administrative autonomy compared to other schools and most are also de facto denominational in terms of their student and teacher composition. In spite of the divided nature of the school system, it should be noted that there are few, if any, religious tests operated by schools for admissions. Crossover in school attendance-Protestant students attending 'Catholic' schools, or Catholic students attending 'Protestant' schools-is possible, if uncommon.

As noted above, various interventions were tried in schools to promote reconciliation or equality, including common curriculum programs, student contact initiatives, the development of new integrated schools and equal treatment for the different school sectors (Arlow 2004; Gallagher 2010; Smith and Robinson 1992, 1996; Matchett 2004; Richardson 1990; Education and Training Inspectorate 2000; Richardson and Gallagher 2010; Standing Advisory Commission on Human Rights 1987, 1990; Osborne et al. 1993, Gallagher et al. 1994). Gallagher (2004) argued that while each of these initiatives had had some impact, there was little evidence any had produced systemic change. Shared Education evolved as an attempt to devise a new initiative that might be more likely to drive systemic change (Gallagher 2016).

\section{Shared Education}

Shared Education essentially involves Protestant, Catholic and integrated schools working collaboratively, to promote sustained and regular contact between students and teachers. This collaboration is focused on high value, core curricular subjects. It will expand opportunity for students and promote school improvement, as well as build connections across the sectarian divide and promote social cohesion. It recognises the different contexts and circumstances of communities within Northern Ireland and so encourages locally tailored programs of between-school collaboration and places high value on the empowerment of teachers as co-creators of collaborative partnerships and practice.

In 2007 the Sharing Education Program (SEP) was established at the School of Education Queen's University Belfast. An implementation team was set up to encourage and support schools across Northern Ireland to establish collaborative partnerships and the work developed over three phases. The first phase, between 2007 and 2010, involved twelve post primary school partnerships, comprising of 3500 students from 65 schools. The second phase, between 2010 and 2013, involved 12 new school partnerships, totalling 72 schools and approximately 5000 students engaged in shared learning. The third phase, between 2013 to the present involves the continuing support of existing partnerships from the second phase and other 
related partnerships. In this phase there were 16 partnerships which involved approximately 4000 students (Duffy and Gallagher 2014, 2015; Gallagher et al. 2010; FGS McClure Watters 2010; see also Donnelly and Gallagher 2008; Daniels et al. 2009; Gallagher and Carlisle 2009; Knox 2010; Borooah and Knox 2013, 2015; Hughes et al. 2012, 2013).

The SEP implementation team was also focused, from the start, on policy impact, and so developed an active strategy for engaging with the main political parties, briefing members of the NI Assembly Education Committee and disseminating evidence of good practice from the work of the Shared Education partnerships. This pro-active engagement process attracted broad political support for Shared Education, evidenced by its adoption in political manifestos leading up to the 2010 Westminster and 2011 Assembly elections, and its adoption in policy and legislation. During the 2011-2016 mandate of the NI Assembly, the SEP implementation team continued to work with political parties to assist in their understanding of Shared Education and provide information regarding the formulation of policy and legislation that would support Shared Education. The evolving significance of Shared Education as a key element in education policy was evidenced by a growing number of Assembly Questions on issues related to Shared Education, examination of the potential of Shared Education by the Assembly Education Committee, (NI Assembly 2014a) and a number of formal debates in the Assembly on the role of Shared Education, (NI Assembly 2010, 2014b). Further discussion on the development of policy on shared education is addressed in the final section of this paper.

\section{Underpinning theory}

The Sharing Education Program at Queen's University Belfast is underpinned by a number of theoretical models, the most important of which draws on social network theory and conceptualises a school system as an interdependent network, rather than a system of largely autonomous units. Conceiving of schools as part of a network opens up the possibility of looking for network solutions. In the case of SEP the aim was to encourage positive interdependencies between schools through collaboration, and it was anticipated that this could be advanced through the sharing of resources and facilities, collaborative efforts to support school improvement, and the promotion of social cohesion through cross-sectoral collaboration.

The work of Katz et al. (2008, 2009), and Katz and Earl (2010) posits a logical relationship between collaboration and school improvement, and identified a series of characteristics which define effective network learning communities:

- the schools should develop an agreed purpose and focus

- relationships between individuals should act to generate social capital

- collaboration should be intensive and capable of changing ideas and practices

- there should be opportunities for collaborative enquiry and professional reflection

- leadership, both formal and informal, should be distributed 
- opportunities for capacity building should be provided to enable individual and collective learning to take place

Katz and Earl (2010: 28) argued that networked learning communities create conditions within and between schools which enable staff to "move outside of their typical contexts to engage with a broader scope of ideas and possibilities' whereby the collaboration of educational staff generates new knowledge and ultimately 'influences practice' leading to improved learning for students and school improvement more generally.

Wenger's $(1998,2000)$ descriptions of effective communities of practice identify how organisations such as schools can act as social learning systems: initially they work best at developing learning when they establish clear boundaries and a strong intra-community focus, but there comes a point where they need to create porous boundaries and bridging processes with other communities of learning in order to advance learning and avoid organisational stagnation (see also Muijs et al. 2010). Research evidence demonstrates that effective collaboration can: help schools; improve student performance and engagement (Chapman and Muijs 2014; Chapman et al. 2009, 2011; CUREE 2005; Hadfield and Chapman 2009; Hadfield et al. 2006); positively impact school leadership (Chapman 2008; Hadfield and Jopling 2012; Hargreaves 2010; Kubiak and Bertram 2010; Harris 2008); and positively impact teacher development, performance and motivation (Ainscow et al. 2006; Chapman 2008; Chapman et al. 2009; Hadfield and Jopling 2012; Hadfield et al. 2006; Harris and Jones 2010; Muijs et al. 2010).

The contact hypothesis is also important as it describes the ideal conditions where engagement between members of different groups can lead to reduced prejudice (Allport 1954). Typically these conditions include equal status between groups, cooperation rather than competition, and legitimacy through institutional support. Working with Northern Ireland samples Hewstone et al. (2008) highlighted the value of sustained, as opposed to short-term contact opportunities; the potential for indirect contact to reduce contact related anxiety; the role of non-contentious super-ordinate goals in contact encounters; and the facilitation of opportunities to develop 'intimate', as opposed to superficial contact. This last point is important as it sees effective contact developing through at least two stages, with initial contact focused on addressing the anxieties of participants from the contact itself, but later stages focused on self-disclosure and the development of trust and friendship: the importance of this development aspect to effective contact is the reason why sustained, long-term engagement is crucial.

\section{The sharing continuum}

Based on the experience of working with collaborative networks of schools in Northern Ireland between 2007 and 2013 the SEP Implementation team developed a conceptual model, or 'sharing continuum', (see Fig. 1) (Duffy et al. 2012; Duffy 2014) the aim of which was to provide: 


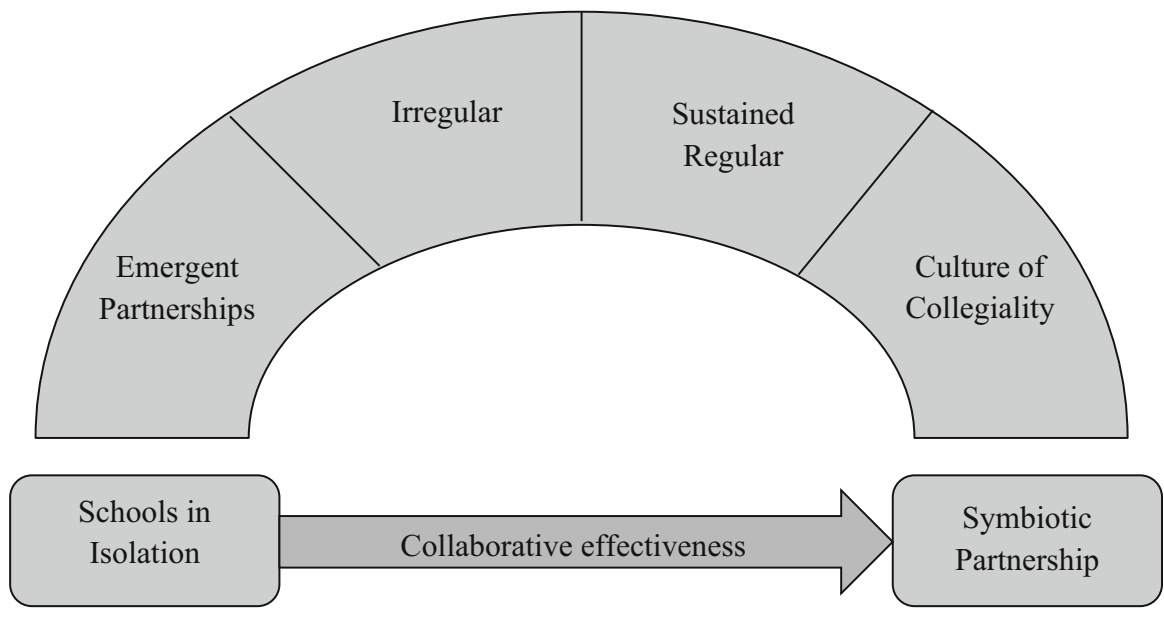

Fig. 1 The sharing continuum

1. A typology of the different types of collaborative arrangements which had developed through SEP in Northern Ireland, and an assessment of their relative effectiveness and sustainability.

2. A policy tool which could be used to locate and evaluate the progress of emerging and new partnerships.

In addition to the experience of the first phase of SEP (Duffy and Gallagher 2014), the 'sharing continuum' also drew from existing research on collaborative effectiveness in educational contexts, most notably Katz et al. (2008), Katz and Earl (2010) and Woods et al. (2006). In this way it sought to provide a 'road-map' whereby school partnerships could develop more advanced and effective arrangements, and work towards a context in which shared learning and broader collaboration was normalised, and hence sustainable. The sharing continuum could be used to locate the position of a school partnership at a particular point in time, help provide guidance on its direction of travel towards enhanced collaboration, and contribute to the evaluation of change within and between schools. The Department of Education for Northern Ireland adopted the sharing continuum in this way (DENI 2014: 57-58) as part of a business case for a new Shared Education Signature Project (SESP) (discussed below), a mainstreamed program which currently supports hundreds of new Shared Education partnerships. The sharing continuum was adapted by the Department of Education into a self-assessment tool for schools applying for SESP: a requirement for this program was that schools were already involved in a collaborative relationship with at least one other school, so, in their applications, schools had to locate their current activity on the sharing continuum and identify targets for progress over time (DENI 2014: 18).

The sharing continuum was not conceived as a deterministic model, nor was it assumed that the development of collaboration would proceed in a simple linear fashion. As a typology and policy tool it reflected the fact that different school 
partnerships begin at different places, are constrained or enabled by different circumstances, and move at different speeds. Furthermore, it allows for the possibility of rapid transit across stages, where circumstances and ambition allowin other words, the sharing continuum was intended to inform and guide, not determine.

The sharing continuum identifies six broad stages of collaboration between schools, each of which will be considered below:

\section{Schools in isolation}

Schools where there is little or no collaboration with other schools.

\section{Organic and emergent collaboration}

Limited contact between schools marking the beginning of collaboration. Organic partnerships come from the schools, whereas emergent partnership is motivated or enacted by an external agency.

\section{Less sustainable and irregular collaboration}

Infrequent but increasing contact between schools: some shared learning may occur between students, but is likely to be programmatic, with delineated periods of contact such as joint school trips or cross-school visits. This level of collaboration is limited in terms of sustainability.

\section{Sustained and regular collaboration}

Increasingly regular and well-co-ordinated collaboration, involving staff and students, over an extended period of time; shared learning between students is regular, timetabled and embedded within the curriculum; schools begin to form partnership infrastructure and professional relationships strengthen.

\section{Culture of collegiality}

Schools have been involved in sustained collaborative activities and are developing strong institutional relationships characterised by high status curricular shared learning between students and increased collaborative activities between teachers and leaders. Management and co-ordination of collaboration is distributed across staff. Both professional and personal relationships emerge between educators. A strong partnership infrastructure is evident and the practice of collaboration begins to normalise. New knowledge and shared resources are created.

\section{Symbiotic partnership}

Schools develop a kind of organisational symbiosis in that collaboration has normalised: it is based on common need, involves significant shared learning, and is 
valued by staff and Governors. Professional and personal relationships are evident. Schools have reached a point where they pool resources in terms of expertise, finances, teachers, and facilities. While the schools remain distinct and maintain their separate identities, collaboration has becomes a vehicle to deliver education more effectively. The sharing continuum posits a logical relationship between collaborative effectiveness and the potential for impact, that is, the more effective the mechanisms of partnership, the more likely those schools will be able to deliver both social and educational outcomes. In the following section we present a Shared Education partnership case study, demonstrating the relationship between effective partnership and impact, but before doing so it is worth considering an issue which emerged as a consequence of the growing focus on sharing as a policy option.

Within Northern Ireland, discussion on the trajectory of school partnerships opened up a debate on their future status and whether they would, or should seek, to become integrated schools. This option exists because parents can vote to transform an existing Protestant or Catholic school into an integrated school, subject to final Ministerial approval. In addition to gaining a majority vote among parents, the school must attract at least $10 \%$ from the minority community in its first intake and increase minority enrolment to at least $30 \%$ of the total, over time. Some argued that shared education initiatives should only be supported if the collaborating schools set themselves on a path that would lead to them becoming integrated schools. The basis for this view was that religiously integrated schools provided the most effective basis for promoting social cohesion and that school collaboration made, at best, only a limited contribution. Gallagher and Duffy (2016) argued that this view was incorrect because it was based on the singular application of a principle of tolerance. If, however, this is set alongside a principle of recognition, they argued, then it becomes clear that no single structural model of schooling unambiguously guarantees either a malign or benign impact on intergroup relations. Furthermore, the focus on single schools takes away from the wider range of positive consequences of sharing, including the more effective use of resources, the contribution to school improvement, and its impact on communities. On this basis Gallagher and Duffy (2016) argued that schools engaged in collaboration should not be obliged to accept a prescribed future, but rather should make their own decisions, in their own time, on how far they want to take their collaboration. It seems likely that some will, in time, explore the option of an integrated school or schools, but it seems equally likely that some will find a modus vivendi of collaboration that maximises the wide range of benefits, while allowing them to maintain their distinctive identities and ethos.

\section{Shared Education in contested space: A case study}

The following section presents a 3 year case study of a Shared Education partnership which sought to transform contested space. Our data, largely qualitative, were collected between April 2011 and June 2014. We begin by introducing the schools, the remit of their partnership and the challenges they faced. We then 
outline the methodology of our study, and provide an analysis of the evidence on the social and educational impact of the partnership.

\section{Introducing the Foyle Contested Space Education Partnership}

The Foyle Contested Space Education Partnership formed in June 2011 and was made up of eight schools-five primaries (3 Catholic and 2 Protestant) and three post-primaries (2 Catholic and 1 Protestant). The partnership was funded by a philanthropic organisation and the Office of The First and Deputy First Minister (OFMDFM), (see Duffy and Gallagher 2015), which established the Interface/ Contested Space fund in order to improve relations between and across disadvantaged contested space/interface communities. The funding program encouraged groups such as schools, youth service providers and community/voluntary organisations to establish projects that could address need, encourage reconciliation and contribute to better outcomes for children, young people and families. Projects had to be located in contested space settings and lie within the bottom quintile of deprived wards in Northern Ireland. The school partnership received a grant of $£ 500,000$ over a 3 year period.

The Foyle Contested Space Education Partnership had evolved from previous collaborative arrangements formed during the Sharing Education Program. For this initiative the partnership addressed a range of social issues for students aged between 8 and 15 years. They connected elements of the primary and post primary curriculum, utilising elements of the Personal Development and Mutual Understanding (PDMU) curriculum at primary level (CCEA 2007a), and Learning for Life and Work (LLW) at post primary level (CCEA 2007b).

The program was delivered on a shared basis with students learning together in each other's schools. The program required the collaboration of teachers and school leaders across the entire city. A total of 1161 students were involved in shared learning, visiting each other's schools on a weekly basis over the 3 years of the program. Eight Principals, three vice principals, 35 teachers (29 primary and 6 postprimary) and one external primary co-ordinator were involved in the delivery of management, coordination and teaching within the partnership.

\section{The remit of the partnership}

As part of the funding conditions schools were required to identify and agree a program of partnership action which would address the challenges of their social context and lay out the basis of their partnership working. Focusing on a series of superordinate goals, they agreed an agenda of issues to address the consequences of social deprivation and promote better educational experiences for their students. The final agreed agenda included the following themes:

- Anti-social behaviour

- Improving community relations in a contested space setting

- Substance misuse

- Health, sexual health and resilience 
- Appropriate and safe use of the internet and social media

\section{Methodology}

The current study employed a multiple-case study design. The eight schools in the partnership operated with an overarching infrastructure, and an agreed agenda for curricular and related interventions. This was operationalised by creating four subpartnerships within the larger network structure, outlined in Table 1, with the subpartnerships being based on collaboration across the denominational sectors, but within age phases, and giving due regard to school size and capacity:

In each of the case studies the authors carried out ethnographic observations in schools, classrooms and other venues. Semi-structured interviews and focus groups were held in each of the schools with school leaders, teachers, partnership coordinators, students and parents. Although there were no focus group or individual interviews with students in the primary schools, during observation exercises it was possible to capture and record informal or unstructured conversations between the researcher and students (Fontana and Frey 2005). In post-primary schools, students were interviewed in focus groups: the initial focus groups used within-school groups of students, but later involved students from two schools. For the most part, school observations took place in years one and two, while interviews and focus groups took place in years two and three.

\section{The challenges of Shared Education}

Participants described various logistical challenges that emerged from providing shared learning for students, some of which had emerged in previous studies (Duffy and Gallagher 2014, 2015; Donnelly and Gallagher 2008). The city in which the school partnership is located is divided to the extent that those living in it cannot agree on a common name for the city: those from a Catholic/nationalist background use its ancient name of Derry, while those from a Protestant/Unionist tradition call it Londonderry, a name attached in the seventeenth century. The city was a focus for allegations of electoral manipulation during the civil rights campaign which preceded the political violence, and it experienced intense civic protests and violence over many years. The city is divided by a river and one consequence of

Table 1 Operational sub-partnerships (case studies) within the Foyle Contested Space Education Partnership

\begin{tabular}{lll}
\hline Case study 1 & Primary school 1 (Protestant) & Primary school 2 (Catholic) \\
Case study 2 & Primary school 3 (Protestant) & Primary school 4 (Catholic) \\
& Primary school 5 (Protestant) & \\
Case study 3 & Post primary school 6 (Protestant) & $\begin{array}{l}\text { Post primary school } 7 \text { (Catholic) } \\
\text { Case study } 4\end{array}$ \\
\hline
\end{tabular}


conflict has been the virtual separation of the communities onto different banks. All of the Catholic schools in the study are located on the west bank or 'Cityside', and all but one of the Protestant schools are located on the east bank or 'Waterside.' Ironically this physical separation of the communities contributed to a tacit agreement between paramilitary factions in the city not to engage in widespread random sectarian assassinations, a characteristic of the violence in other parts of Northern Ireland. This represents a good example of bounded contentment (Roche 2009) in that the communities were largely apart, stayed apart and had little interest in changing this situation. Our participants reflected this as they talked about how they navigated the city, tending to avoid areas that 'belonged' to the other community:

GD: Would you have much contact with people from the Waterside or would you have much contact with Protestants?

Parent: No, she's the only one [talking about a Protestant friend]. [...] Everybody who comes out that tunnel, they're from the Fountain [Protestant area] [...] If you go in that tunnel you're from the Fountain. You wouldn't get me going in the tunnel. (Catholic Parent)

\section{Transporting students}

In the course of the study, educators, students and parents talked about sectarian tensions, violence in the city, and disputes over flags, emblems and other cultural symbols. They highlighted the anxiety associated with visiting the other community and how they preferred to remain within their own communities, using 'their own' facilities, amenities and institutions:

FP1: I wouldn't even come near here, because I just think I could be hit by something, or bottles or anything being chucked [thrown] at me. [...]

FP2: And like when me and [Student 1] were over the town (City-side) like I had a Union Jack bag on and we saw some [School 8] people, and they looked at me weird and I just felt like turning the bag around so they wouldn't see it. (Case study 4, School 6, Year 9: Single identity focus group)

One of the priorities of the partnership was to break down this real division by encouraging students to visit each other's communities and learn in each other's schools. Over the 3 year period of the program, students typically visited each other's schools once a week for 3 years, but had to be bussed due to the distances involved. This raised logistical challenges such as organising bus companies to move hundreds of students, without spending too much time travelling, and all within a coordinated set of timetables. These practical challenges were constantly highlighted by teachers:

It's your practical things like the school days don't match up. [...] So if I leave here, you'll find tomorrow I should be in School 7 for ten to or five to eleven and we can stay until twelve o'clock. And that gives you a good hour of work. [...] Whereas when the other two ladies travel here, you are 
talking 45/50 min maximum for a lesson, and I find that very, very tight to get anything meaningful done because I feel more rushed. (Teacher: School 6)

\section{Available space}

For some of the schools, accommodating visiting students was challenging, simply because of the size of the school and available space. During one observation exercise we saw students from 1 year group in Schools 3 and 4 visit School 5, but since this is a small school, the total number of visitors was equivalent to the entire school population of School 5:

We only have eighty four students in the school, so that's like [bringing in] another school [Laughter].Well we managed, between my classroom and a Portakabin, and the canteen. We just split them in two, forty odd in each, so we got them all squeezed in. (Leader: School 5)

Co-ordinators were appointed to manage the logistics of shared learning. The primary schools appointed an ex-teacher who had taught in the city for over two decades, while the post primary schools appointed an existing teacher to manage the project in each school. School leaders from both primary and post primary schools acknowledged the importance of the co-ordinator role:

I don't think the project would be as successful. I would even go so far as to say I would not be sure it would work nor would it be sustainable without a project manager, which is really what [Primary Co-ordinator] is. Her role this year has grown considerably [...] (Leader: School 1)

\section{Sustainability and funding}

Leaders and teachers were of the opinion that the sustainability and the reach of the partnership depended on funding. Over the course of the 3 years, funding was used to transport students between schools, provided a management allowance for post primary co-ordinators, allowed the appointment of a primary co-ordinator, paid for venue hire for seminars and events, covered the cost of catering, supported training and capacity building for staff, and covered the cost of substitute cover for teachers when required. Educators questioned what types of activities could be sustained without funding and expressed some concerns that they might not be able to sustain the transport of students between schools. They also questioned the level or the scale to which they could sustain shared learning between students. However educators hoped that the partnership would evolve, rather than dissolve, when the funding ceased. They committed to search for additional funding or to adjust the remit or extent of the partnership in line with whatever funding was available. There was a broad consensus that Shared Education between students and collaboration between staff would continue in some form: 
So you've got a strong partnership and therefore no matter what, we will continue with this, whether there's money there or not, because we will find the money to do it, we might not do everything, but the partnership will exist and there will be shared workings between the schools [...]. (Leader: School 1)

\section{The social impact of Shared Education}

\section{How Shared Education helps reframe contested space}

The Shared Education partnership challenged denominational and professional isolation by facilitating and supporting the movement of 1,161 students across the schools into each other's communities over a regular and sustained period of time. Students and educators had meaningful contact on a weekly basis where they engaged in shared curricular learning, and had formal and informal opportunities to explore each other's cultural backgrounds. Collaborating schools helped reframe the contested space so that the institutional boundaries between the schools started to blur (Gaffikin et al. 2008). This idea is borne out in the comments made by a school leader:

The schools that we're working with are a big part of the population, and therefore if you are tackling that from nursery, as we are right through now to Primary 5, 6, and 7, with the Contested Space Project, surely they're going to see that's going to run parallel with the developing space, with the developing city centre, and I think those things will merge, where people are comfortable, young people are comfortable moving from one space to another. (Leader: School 1)

\section{Relationship formation and anxiety reduction}

Over the period of the study our evidence suggested that personal and professional relationships formed between students and between educators. In some cases these relationships extended beyond the remit of the program and developed into real friendships. Students described making friends in various ways, including the formation of friendship groups during shared lessons, or meeting each other outside of school, or through social media. All of this enabled students to sustain links outside of the shared classroom:

GD: How many friends from School 7 do you think you have on Facebook?

FP1: About seven, eight

GD: And are they all from your shared class as well?

FP1: Yeah. [...]

MP2: On Facebook I have about four or five, maybe six

MP: Aye, but you have four different Facebooks

MP2: (Laughs)

GD: Okay. I won't ask. So what types of things are talked about on Facebook?

FP1: Like "What are you doing tonight?" 
MP1: For "What's the craic?" [...]

GD: And what about friendships that aren't in the cyber world? [...]

MP1: Well, on Hallowe'en night I was out with a couple of them. I met them up on the town [...] Just watching the fireworks

(Case Study 3, School 6, Year 9: single identity focus group)

Primary school students were very enthusiastic about opportunities to make friends, often citing this, along with working and playing together, as their most favourite aspects of shared learning.

GD: Tell me what you think the best thing is, about doing this?

MP1: We get outside, and I like being here because it is nice, and I make new friends. I just like it!

GD: And you make new friends [...] like new friends from different schools?

MP1: I have made two new friends, him, him and one other boy

(Case study 1, School 2: Year 6)

Teachers and leaders talked about texting and emailing each other and socialising outside of school hours. Importantly these relationships did not exist prior to becoming involved in Shared Education:

Genuine friendships have been built here. [...] I never ever would have built the relationships, professional or personal, with them and I'd now consider them to be my closest friends and allies in this profession. I really do, most sincerely. (Leader: School 1)

Shared Education provided students from different communities with opportunities for sustained contact. Over time, evidence demonstrates that, as students got to know one another better, anxieties reduced and prejudices abated:

I remember the first time we ever went over to [the other school], our children were very, very apprehensive and so were our bus drivers, because we were in our school minibus with our logo, and now, I don't think anybody thinks twice about it now. [...] you build up in your head that if you do this, something will happen. If we go here in our school uniform, somebody is going to hurl abuse at us. Or if we go about the [Catholic side] in our minibus, somebody will throw stones at it. And then when things like that don't happen you, sort of, start to go, 'Right, now it's okay.' Nobody really notices. We walk in and out of other schools and nobody says, 'why are you here?' or, 'what are you doing? You shouldn't be here.' As time goes on, and as the children talk to the other children, it has a positive impact. (Teacher: School 6)

Similarly, the following transcript extract highlights how student's levels of anxiety associated with Shared Education reduced over time as they get to know each other better:

GD: So you all mentioned that when you first started doing this in September that were you nervous? [...] why do you think you were nervous?

FP3: Because, like, the other people in the school, like, stared at you 
GD: So you're more nervous about other people rather than the group you're going to meet. And the staring thing, does it still happen?

FP3: Not any more, it doesn't. [...]

FP1: Because you get to know people more and you keep going over there and over and then they'll just start getting used to more people coming over. (Case Study 3, School 6, Year 8: Single identity focus group)

\section{Improving connections between schools and community services}

Another social impact which emerged from the partnership was improved interconnectivity between the schools and external agencies based in the community. They agreed that some of the issues they wanted to address could only be dealt with effectively if they involved external expertise. For example, the primary schools explored the theme of anti-social behaviour by looking at littering and graffiti in the city. They invited guest speakers from the Police Service of Northern Ireland (PSNI), the City Council and City Wardens, and toured the city with a guide who took students to litter hotspots and identified places where graffiti was problematic. The range of external agencies that visited and worked with the schools included:

- The Police Service of Northern Ireland (PSNI)

- Child Exploitation and Online Protection Centre (CEOP)

- National Society for the Prevention of Cruelty to Children (NSPCC)

- The City Council

- Community Wardens

- Social Housing Associations

- Youth Services

- Local Health Centres and General Practitioners

The role of the PSNI here is particularly noteworthy. Historically, there has been a poor relationship between many nationalist communities and the police (formerly known as the Royal Ulster Constabulary (RUC), but now known as the PSNI after a series of significant reforms). This has arisen for a number of reasons: few Catholics joined the police in Northern Ireland, and Catholic communities often felt they received unfair and unwarranted attention from the police. More seriously, there have been accusations of human rights abuses and alleged cases of collusion between police officers and Protestant paramilitaries. This legacy has made it difficult for the police to build trust within nationalist communities. A practical consequence was that police officers rarely visited Catholic schools in some areas, thereby limiting the potential for community policing. The Catholic Church and CCMS, in 2011, as part of a peace building strategy, held discussions with the PSNI and endorsed a program to enable police officers to visit Catholic schools. Not unexpectedly this faced resistance in some communities, including parts of the city in which our study is based. Parents and local community representatives voiced their concerns in the media and some parents suggested that the PSNI would use 
access to schools as a long term strategy for recruiting Catholics. Within the Contested Space Partnership, the PSNI regularly visited most of the schools, some of which were in nationalist communities. The police delivered lessons on internet safety, anti-social behaviour and substance misuse as part of a broader community safety strategy. There were two schools which the police could not visit because of parental objections and concerns expressed by school governors, but no-one objected to the children from these schools visiting partner schools where police officers were able to deliver lessons in shared classrooms:

There's at least two schools where, although I have a thriving relationship with the principals of the schools and communicate with them possibly monthly [at] this point in time I would not be in a position to go into the schools to deliver a lesson around internet safety [...] at this point it's too delicate, and we are aware of the Facebook sites and the other sites that really make it clear that we're not welcome in those schools at the minute. However, through the project we have spoken to those kids and that's what's important. It's not really about getting into that particular school, what's important is that we see the children that go to that school. And we have seen them in a Shared Education environment. (PSNI Representative)

Analyses of interviews involving representatives from the PSNI and school leaders revealed that a high degree of cooperation and trust had emerged, largely stemming from the decision to invite the PSNI to sit on the partnership steering group.

\section{The educational impact of collaboration}

In the next section we will examine the educational impact of Shared Education using three exemplars: first, we will consider students' perspectives on shared learning; second, we will look at the impact of collaboration on teachers and leaders; and, third, we will consider a specific example which demonstrates a positive improvement outcome for two schools which was enabled as a consequence of the relationship they had developed through collaboration.

\section{Student perspectives on shared learning}

Observations in classrooms and focus group data revealed that shared learning had a positive impact on students. In summary, the evidence suggested that students enjoyed learning together and that they emphasised the merits of using active pedagogical approaches. The data provided further insight on how students interacted, and provided examples of how students explored and learned about each other's cultural backgrounds, and explored social themes:

MP1S1: We go to a school each week. They are coming to our school next week. And then we are going to their school

GD: And so do you do this, swapping about?

MP1S1: Every week 
GD: And guys, what do you think of it? Do you enjoy it?

MP1S1: I love it! [...] I hope it goes on forever! (Case Study 1: Year 5)

Students made comparisons between shared classes and their 'normal' single identity classes. One of the reasons students enjoyed Shared Education was because it offered variation or diversity in terms of style and approaches to learning:

MP1S6: If anything it's one of the best times in the school week because it's different

FP2S6: Instead of being in a class and writing and writing. (Case Study 4: Year 10)

Typically teachers employed active teaching methodologies favouring strategies such as group discussions, debates and games. This approach encouraged groups of students from each school to form and work together:

If we did it [LLW] in our own schools we wouldn't really be sitting talking in groups, we'd probably just be told we have to do this here, and the teacher would have to tell us about it instead of the other school then can tell us about what they do, and we can tell them what we do. It's good, the way we can share what we do in our lives. (Case Study 3, School 7 Year 8: shared focus group)

Observations of groups of students working together in both primary and post primary settings revealed rich social activity. Group dynamics were not entirely characterised by studious students focused on achieving goals and tasks set by the teachers, but rather our observations revealed a type of wavering, between students working together to meet assigned tasks, and off-topic conversations which provided opportunities for students to get to know more about each other. Conversations would often focus on students' backgrounds, religion, music, sport, hobbies and the local context of the city. While themes around community relations, cultural differences and commonalities were explored explicitly in shared lessons, in both primary and post primary settings, often, these themes were also explored implicitly and informally by students in groups as they got to know more about each other's backgrounds. In the transcript extract below, a student from the Protestant post primary school explains how he came to understand more about the Catholic tradition of Ash Wednesday:

MP1S6: We do a wee bit of talking about it

FP1S8: Aye we do I chat to, what do you call her with long blonde hair?

FP2S6: [Catholic student]

FP1S8: Her, I chatted to her about it because she was asking me what all these Republican groups are and all and I was just telling her

GD: $\quad$ So these things happen when you guys are in classrooms, in smaller groups? [...]

MP1S6 : Like Ash Wednesday and all that like, I didn't know what it was. When I was [younger] I thought everybody had a dirty face, I thought everybody was like dirty. (Case Study 4, Year 10: shared focus group) 
The following example, based on observation notes, describes how mixed groups of primary school students explored a Catholic church together:

The students are very engaged in the church tour and have time to wander around unaccompanied at the end of the presentation. Some of the students, a mixed group, are discussing if they can walk on the altar. The students approach me and ask if it is ok. I tell them that they should ask the tour guide. Meanwhile another mixed group have gathered in front of a confessional booth. They appear curious and eventually open the door to look inside; they are looking around for teachers to confirm if this is ok. (Observation notes, Case Study 2: P7)

Evidence suggests that themes including substance misuse, anti-social behaviour and internet safety were the most popular and impactful. In shared lessons we frequently observed students involved in animated and well informed discussions and debates, supplemented by student reflection and sharing of personal narratives:

Another girl shares a story about neighbours having a party and being very loud in the street. She explained that a man came out of the house and got into a car and was doing skids up and down the road. The warden explained that they can come out and help in situations like this. He told the student that this was a good example of the type of work that the wardens do. (Observation notes, Case study 2: P7)

There was some evidence, particularly from older students, that addressing themes such as alcohol and anti-social behaviour in shared classrooms had a preventative impact. The following transcript extract provides an insight into the social pressures facing children and young people in the city. The students are describing the impact of a lesson where the PSNI used CCTV footage of young people drinking on the streets in the city. It is worth noting that students were aged between 14 and 15:

FP1S6: I used to drink on the streets until the police and all came in [shared lessons in school]. That's what made me stop. I don't anymore

GD: Right. And so what's it like to have the police and community wardens coming in and talking about that kind of thing?

FP1S6: It's scary

GD: $\quad$ So does it hit home with you?

FP1S6: Aye, it does hit home with me

GD: $\quad$ Right. So would it have an impact?

FP1S6: Aye, definitely

GD: Right, okay. Do you have mates or friends that maybe go out [drinking]?

FP1S6: Aye, see it's the crowds you run about with. It's the crowd I started to run about with

MP1S6: Everybody's at it

GD: Right. And so what's it like then to have somebody coming in and talking about this kind of thing as a subject?

MP1S6: It's good, it lets you know 
FP1S6: It's good, I enjoy it

GD: Right. So you feel it's having an impact or is any of it just a waste of time and just people...?

MP2S6: Definitely not, because it's a warning more or less to what could happen to you, like with the drink and the drugs and stuff. (Case Study 4, Year 10: shared focus group)

\section{Professional development, capacity building and supportive educator networks}

Teachers and school leaders talked at length about the benefits of working together, describing professional development opportunities and the formation of supportive educator networks. In one example a school leader described the role of Principal as being 'lonely' and welcomed the opportunity to work more closely with other Principals. They also indicated that because relationships between Principals were so good, they would be more inclined to contact cross-sectoral leaders in partner schools. Prior to Shared Education, contact with colleagues from schools in other sectors would have been limited, and opportunities for more informal engagement across the sectors would have been even more limited. School leaders talked about how collaboration created deeper institutional relationships and supportive networks, which in turn enabled leaders to trust one another, to ask for help or guidance and to share expertise:

I could phone [the Principal School 6] tomorrow and go back over there for anything, I mean, I would, and I would never anticipate that somebody would say no. [...] I really think that there was a sense of trust. [...] we know each other as well as we know staff within our own schools. (Leader: School 7)

Collaboration provided opportunities for educators to be exposed to a much broader professional pool. Teachers emphasised the value of simply being able to talk to each other. For some, there was recognition that irrespective of their sectoral differentiation, they faced common professional challenges and their students faced the same social pressures growing up in the city:

Being able to work with other schools, being able to just talk to other teachers about what's going on in their school and seeing that our problems are their problems, even just getting solutions to things. [...] I've made really good friends. But it just gives you a really good insight into how they think. (Teacher: School 6)

Teachers highlighted that collaboration allowed them to share resources, as well as generate new knowledge and practice, and minimise duplication:

That's the good thing, that we were able to share a lot of things. We all came together and we planned, but like the things we then produced, and the resources, the good thing was that every school wasn't going back and doing the same thing. (Primary 5 teacher: focus group) 
Given the five social need themes at the heart of the partnership, teachers frequently talked about their capacity to deliver shared lessons. While for the most part they were comfortable addressing these themes, there were times when they felt that their capacities were challenged. For some teachers addressing themes such as community relations, the past, cultural symbols such as flags and emblems in shared classrooms provided challenges. Staff addressing these issues in shared classes found it challenging and expressed differing levels of anxiety. In one instance a post primary teacher describes opting to avoid addressing flags and emblems in the classroom, but seeing the issue emerge from the students anyway:

I was taking the safe road, but I remember consciously avoiding what was written on the page which was flags and emblems because I know how strongly this community feels about flags and emblems at the minute. I thought at the time, and it was like, I am not inflaming this any further. But in the end up it actually came round, they ended up talking about it themselves anyway. (Teacher: School 6)

Some teachers even differentiated between 'more acceptable' and 'less acceptable' controversial issues: we were told by some teachers that they were more comfortable addressing issues such as sexuality or sexual health in shared settings, rather than having to address issues relating to politics or cultural differences:

There's no difficulty addressing contentious issues to do with alcohol or sexuality, those tend to be easier for them. I would say it's the political ones, the real kind of humdingers, that they're just... I suppose still nervous of. (Leader: School 7)

For others, there were concerns about upsetting or offending students in class and by extension upsetting parents from both traditions. A school leader suggested that while there is a statutory duty on teachers to address challenging themes as part of the curriculum, there were concerns about agitating parents or being subject to litigation. External agencies were often deployed in the early stages to build capacity amongst teachers on these issues, and to encourage them to share resources and present in shared classrooms. A school leader explained that schools in the first year of the partnership recruited an outside agency to assist teachers to address themes such as identity and community relations. However, in years two and three of the program teachers felt more confident in their ability to address these themes and no longer required external assistance:

That was a very real issue for staff at the very start when we embarked on this project and I know [the Primary Co-ordinator] outsourced people to come in that were mediators and, you know, people that were used to dealing with confrontation and reconciliation and that type of thing. [...] There are ways of approaching things and you can do it without being offensive and I think they picked those skills up from the mediators and then that's what I'm saying about capacity building, I think this year they've been able to take on board that and deliver those projects themselves a lot more comfortably. (Leader: School 2) 
Lastly, informal support and capacity building structures also emerged between teachers involved in the partnership. Teachers described that working collaboratively provided them with opportunities to support each other.

\section{School improvement}

The following provides an example of how collaboration can lead to school improvement. During the period of data collection, the Protestant post primary school in the partnership had been placed into formal intervention by the Education and Training Inspectorate (ETI) (the body responsible for inspecting schools) - a mechanism whereby a school is deemed to need focused support because it is offering less than satisfactory provision. The school's science department was deemed inadequate after inspection. In response, one of the Catholic partner schools, which is a specialist science school, offered to assist its Protestant neighbour to improve its science provision. The Catholic school made its head of department, science teachers and resources available to their counterparts in the Protestant school, and staff from both schools met regularly to share practice. One of their key activities was an audit of the qualification pathways offered to students by the Protestant school. The Catholic school suggested that the types of qualifications offered by its partner were narrow and overly traditional, and did not cater for different learning abilities and interests of their students. Importantly the relationship between the schools was deep enough that critical but constructive comments could be made without the risk of damaging the partnership:

You weren't coming there to attack them or to teach them how to do it properly. And the easiest way to do that was through the curriculum, and say look, leaving everything else aside, the reason your children are not achieving the way they should is that they are not actually doing the right courses in the school. [...] That was something we had done a lot of work on; we had a lot of different science courses running to meet the needs of the different levels of ability of our students. (Leader: School 7)

The schools spent a number of months between 2012/2013 working together on improving the science provision. When the inspectorate returned the science department in the Protestant school was rated as 'outstanding'. The school leaders at interview attributed this improvement directly to the collaboration between the schools:

When we went into formal intervention, I mean they all rallied around, you know, I mean [Leader, School 7] was over like a shot. What can I do for you? Whatever you want, whatever you need, whatever teachers you want to talk to. (Leader: School 6)

A culture of collaboration, whereby schools share expertise and resources, has now emerged between the three post primary schools and is being sustained. (This also applies in the primary context). Importantly collaboration has broadened beyond the remit of the contested space program and is evident in other curricular areas and departments: 
The thing that we felt really needed to be done was our middle managers, and I was able to go and speak to [Leader School 7] and speak to [Leader School 8] about how they developed their middle managers and the sort of programs they used to do that, and to me, it was a great help to see how to develop those [...] it has been a great learning experience, not just for the youngsters but for staff as well. (Leader: School 6)

By way of reciprocation the leader of School 6 explained that their school offered a particular expertise and proficiency in terms of working with students with special educational needs. The school leader explained that this expertise was offered to the two maintained schools.

So we have now been able to share our teaching methods and the way we do things with the other schools. We also are strong in special needs, and (Leader School 7) has asked if there is something we can do around special needs. (Leader: School 6)

\section{Conclusion}

As is the case in many divided societies, schools in Northern Ireland have been expected, for decades to carry the burden of preparing young people to live and work in a divided society, and contribute to promoting reconciliation and overcoming division. For over 30 years this was pursued through short-term contact initiatives, the development of common curriculums and textbooks, the establishment of religiously integrated schools, and equal treatment for minority schools. The emerging peace process provided an opportunity for an evaluation of these initiatives, and the main conclusion was that their systemic impact had been limited. The new model of Shared Education outlined in this paper was developed to address many of the limitations of previous approaches by embedding collaboration at the heart of schools' priorities, providing regular and sustained contact, and locating social cohesion goals alongside educational and economic priorities. This model encourages and supports schools to work together in collaborative networks as a way of bridging the institutional boundaries which have, in the past, divided schools, and turned what had been 'contested space' into shared and connected space within the education system. The case study partnership presented in this paper provides an example of the transformative potential of this approach: the schools have developed bridging mechanisms, and their connections are increasingly elaborate, innovative and robust. It is perhaps also important that connections address issues not only of importance in educational terms, but also that reflect community priorities.

When we consider this case study in the light of the sharing continuum, and the characteristics of effective collaboration as outlined by Katz et al. (2008) and others, the evidence shows that a culture of collegiality is developing between the schools. The partnership has an infrastructure which has both leader involvement and endorsement; shared learning between students is regular and sustained; teachers are planning together, co-teaching, creating new resources, and developing new 
practices; and the experience of shared learning and collaboration between staff appears to be normalising. While the main focus of the partnership involves the delivery of a social needs program, there is evidence of collaborative transfer to areas beyond the prescribed remit of the partnership, as in the example of school improvement where post primary schools have explored science, provision, special education needs and strategies to improve middle management.

The paper also considers evidence on the social impact of school collaboration. Sustained and regular contact between students and between educators has encouraged the development of multiple layers of relationships (Moolenaar et al. 2012), including professional and personal relationships. The design of the partnership has also strengthened relationships between schools and statutory/ voluntary bodies within the community.

In little over a decade, the language and practice of Shared Education is now commonplace in Northern Ireland and is being mainstreamed in government policy and practice. The 2011-2015 Program for Government included formal commitments to Shared Education goals (NI Executive 2011) and established a Ministerial Advisory Group which recommended the further development of Shared Education (Connolly et al. 2013). The Shared Education Signature Project (SESP) is government funded and managed by the Education Authority to support shared learning and school collaboration between 2015 and 2019: at the time of writing over 120 partnerships have applied for support from SESP and it is envisaged that this number will more than triple within a few years. A further tranche of funding will be provided through the European Union Peace IV initiative, this time aimed at supporting schools that do not already have collaborative relationships. The Shared Campuses initiative has been agreed between the political parties in Northern Ireland to support capital developments in which separate schools will re-locate to a single campus, share core facilities and promote shared learning amongst their students.

There have also been legislative developments. The Education Act (Northern Ireland) (2014) placed a duty on the Education Authority to 'encourage, facilitate and promote Shared Education', while a similar responsibility has been allocated to the Department of Education through the Shared Education Bill (2016). The 2016 law also provides a legal definition of Shared Education.

The case study schools discussed above still collaborate. The two primary schools, and the three post primary schools, were successful in separate bids to SESP. Their students and teachers continue to learn together, and from each other. In addition, the case study schools have applied to the Shared Campus fund with the aim of establishing an information technology hub to work across all the schools in the city of Derry/Londonderry. Shared Education is becoming enshrined in policy and legislation and for these schools it is becoming part of what they ordinarily do. Shared Education is moving beyond the status of a project and continues to shape the future direction of education in Northern Ireland.

As Shared Education continues to roll out across Northern Ireland, the diversity of partnerships does raise its own challenges. The success of SEP to date has been based on a bottom-up approach which empowered teachers and encouraged innovation, which is largely why the different partnerships involved, across the 
three phases of SEP, have varied so much. This seems to be important, however, not least because the circumstances of, and opportunities for schools varies considerably. Now that the main shared education programs are funded, supported and managed by government and public bodies, there is always the risk that its creative and innovative edge may become somewhat muted. If this leads to a disempowerment of teachers, a characteristic that is perhaps unfortunately not uncommon on top-down government initiatives, then an important source of energy behind shared education work may be weakened. That said, such effects may be an inevitable consequence of mainstreaming.

Shared education faces other challenges: we have noted above the debate which emerged on whether shared education initiatives between schools should be predicated on their commitment to work, explicitly, towards the development of religiously integrated schools. Some of the critics of shared education have suggested that it may be little more than a fig leaf, a gesture towards social cohesion which can be supported by the Churches and the political parties in Northern Ireland, but doesn't actually require them to make any significant changes to the institutional mechanisms that have reflected or reinforced community division for decades, if not centuries (Hansson et al. 2013). The evidence considered here, and in the wider literature on shared education, would suggest this concern is probably misplaced.

As the experience of shared education expands, so too the evidence base on its effects, and our understanding of the processes of sharing, also expand. Hughes and Loader (2015: 1142), for example, have argued that the impact of Shared Education might be stymied by foregrounding educational priorities over reconciliation priorities and that the full potential of Shared Education can only be realised when schools engage directly and quickly with issues of group difference. As the case study above suggests, however, it is questionable whether schools would have engaged in the process of collaboration at all if it had adopted a unitary, or even primary, focus on reconciliation right from the start. The evidence of Hughes and Loader (2015) does, however, serve as a timely reminder that the long-term goal of promoting social cohesion should not be allowed to disappear. This issue arises in another way due to an emerging international interest in the shared education model. The current authors are engaged in two international projects where the model has been adopted and adapted: in Israel the model has been used to support collaborative engagement between Jewish and Arab schools within the context of the Shared Life initiative pursued by the Centre for Education Technology (Payes 2015), and here the primary focus is very much on social cohesion. The second project operates within the very different context of Los Angeles Unified School District (LAUSD) where relationships between traditional public and charter schools have been, at best, difficult. The authors are currently exploring the relationship between co-locations in which traditional public schools have been obliged to share facilities with charter schools. Both these contexts, the divided society of Israel, and the 'shared' co-locations of Los Angeles schools, provide different types of contested space, and both want to explore also whether that contested space can be turned to more positive affect. 
Open Access This article is distributed under the terms of the Creative Commons Attribution 4.0 International License (http://creativecommons.org/licenses/by/4.0/), which permits unrestricted use, distribution, and reproduction in any medium, provided you give appropriate credit to the original author(s) and the source, provide a link to the Creative Commons license, and indicate if changes were made.

\section{References}

Ainscow, M., Muijs, D., \& West, M. (2006). Collaboration as a strategy for improving schools in challenging circumstances. Improving Schools, 9, 192-202.

Allport, G. W. (1954, 1979). The nature of prejudice (Unabridged, 25th anniversary ed.). Reading, MA, London: Addison-Wesley.

Anderson, B. R. (1991). Imagined communities: reflections on the origin and spread of nationalism (Revised and extended ed.) London: Verso.

Arlow, M. (2004). Citizenship education in a divided society: the case of Northern Ireland. In S. Tawil \& A. Harley (Eds.), Education, conflict and social cohesion. Geneva: International Bureau of Education.

Borooah, V., \& Knox, C. (2013). The contribution of Shared Education to catholic-protestant reconciliation in Northern Ireland: a third way? British Educational Research Journal, 39(5), 925-946.

Borooah, V., \& Knox, C. (2015). The economics of schooling in a divided society: The case for Shared Education. Basingstoke: Palgrave Macmillan.

Centre for the Use of Research and Evidence in Education (CUREE). (2005). Systematic research review: The impact of networks on pupils, practitioners, organisations and the committees they serve. Nottingham: National College for School Leadership.

Chapman, C. (2008). Towards a framework for school-to-school networking in challenging circumstances. Educational Research, 50(4), 403-420.

Chapman, C., \& Muijs, D. (2014). Does school-to-school collaboration promote school improvement? A study of the impact of school federations on student outcomes, school effectiveness and school improvement. An International Journal of Research, Policy and Practice, 25(3), 351-393.

Chapman, C., Muijs, D., \& Collins, A. (2009). The impact of federations on student outcomes. Nottingham: National College for School Leadership.

Chapman, C., Muijs, D., \& McAllister, J. (2011). A study of the impact of school federation on student outcome. Nottingham: National College for School Leadership.

Connolly, P., Purvis, D., \& O'Grady, P. J. (2013). Advancing Shared Education: Report of the Ministerial Advisory Group. Belfast: Queen's University Belfast.

Council for the Curriculum, Examinations and Assessment (CCEA). (2007a). Personal development and mutual understanding for key stages $1 \& 2$ : Guidance notes. Belfast: CCEA.

Council for the Curriculum, Examinations and Assessment (CCEA). (2007b). Learning for life and work for key stage 3: Guidance notes. Belfast: CCEA.

Daniels, H., Edwards, A., Engestrom, U., Gallagher, T., \& Ludvigsen, S. R. (Eds.). (2009). Activity theory in practice: Promoting learning across boundaries and agencies. London: Routledge.

Department for Education Northern Ireland. (2014). Business case: Delivering social change signature project Shared Education Programme. Belfast: Northern Ireland Executive.

Donnelly, C., \& Gallagher, T. (2008). School collaboration in Northern Ireland: Opportunities for reconciliation?. Belfast: Queen's University.

Duffy, G. (2014). Evaluating collaborative effectiveness in schools: A working paper. Belfast: Queen's University Belfast.

Duffy, G., \& Gallagher, T. (2014). Sustaining school partnerships: The context of cross-sectoral collaboration between schools in a separate education system in Northern Ireland. Review of Education, 2(2), 189-210.

Duffy, G., \& Gallagher, T. (2015). Collaborative evolution: The context surrounding the formation and the effectiveness of a school partnership in a divided community in Northern Ireland. Research Papers in Education, 30(1), 1-24.

Duffy, G., Gallagher, T., Stewart, A., \& Baker, M. (2012). Demonstrating how school partnerships evolve to become effective collaborators: Supporting the Programme for Government Commitment on 
Shared Education. Presentation at the annual Sharing Education learning forum conference. Riddel Hall Queen's University Belfast.

Education Act (Northern Ireland) 2014. (2014). London: The Stationery Office.

Education and Training Inspectorate. (2000). Report on a survey of provision for Education for Mutual Understanding (EMU) in post-primary schools. Bangor: Department of Education.

FGS McClure Watters. (2010). The Sharing Education Programme attitudinal survey results. Belfast: FGS McClure Watters.

Fontana, A., \& Frey, J. H. (2005). The interview: From neutral stance to political involvement. In N. K. Denzin \& Y. S. Lincoln (Eds.), The Sage handbook of qualitative research (3rd ed., pp. 695-728). Thousand Oaks, CA: Sage.

Fraser, M. (1974). Children in conflict (New ed.). Hammondsworth: Penguin.

Gaffikin, F. Mc Eldowney, Rafferty, M. G., \& Sterrett, K. (2008). Public space for a shared Belfast: A research report for Belfast City Council. Belfast: Queen's University Belfast.

Gallagher, T. (2004). Education in divided societies. Basingstoke: Palgrave Macmillan.

Gallagher, T. (2010). Building a shared future from a divided past: promoting peace through education in Northern Ireland. In G. Salomon \& E. Cairns (Eds.), Handbook of peace education. New York: Psychology Press.

Gallagher, T. (2016). School collaboration and Shared Education in a divided society. Oxford: Oxford Review of Education.

Gallagher, T., \& Carlisle, K. (2009). Breaking through silence: tackling controversial barriers through inter-professional engagement. In H. Daniels, et al. (Eds.), Activity theory in practice: Promoting learning across boundaries and agencies. London: Routledge.

Gallagher, A. M., Cormack, R. J., \& Osborne, R. D. (1994). Religion, equity and education in Northern Ireland. British Educational Research Journal, 20(5), 507-518.

Gallagher, T., \& Duffy, G. (2016). Recognising difference while promoting cohesion: The role of collaborative networks in education. In I. Honohan \& N. Rougier (Eds.), Tolerance and diversity in Ireland. North and South, Manchester: Manchester University Press.

Gallagher, T., Stewart, A., Walker, R., Baker, M., \& Lockhart, J. (2010). Sharing education through schools working together. Shared Space, 10, 65-74.

Graham, B. (2006). Contested images of place among Protestants in Northern Ireland. Political Geography, 17(2), 129-144.

Hadfield, M., \& Chapman, C. (2009). Leading and developing school-based networks. London: Routledge.

Hadfield, M., \& Jopling, M. (2012). How might better network theories support school leadership research? School Leadership \& Management: Formerly School Organisation, 32(2), 109-121.

Hadfield, M., Jopling, M., Noden, C., O'Leary, D., \& Stott, A. (2006). What does the existing knowledge base tell us about the impact of networking and collaboration? A review of network-based innovations in education in the UK. Nottingham: National College for School Leadership.

Hansson, U., O'Connor, U., \& McCord, J. (2013). Integrated education: a review of policy and research evidence. Coleraine: Ulster University Unesco Centre.

Hargreaves, D. (2010). Creating a self-improving school system. Nottingham: National College for School Leadership.

Harris, A. (2008). Distributed school leadership: Developing tomorrow's leaders. London: Routledge.

Harris, A., \& Jones, M. (2010). Professional learning communities and system improvement. Improving Schools, 13(2), 172-181.

Hayes, B. C., McAllister, I., \& Dowds, L. (2007). Integrated education, intergroup relations, and political identities in Northern Ireland. Social Problems, 54(4), 454-482.

Heskin, K. (1980). Northern Ireland: A psychological analysis. Dublin: Gill and Macmillan.

Hewstone, M., Kenworthy, J., Cairns, E., Tausch, N., Hughes, J., Tam, T., et al. (2008). Stepping stones to reconciliation in Northern Ireland: Intergroup contact, forgiveness and trust. In A. Nadler, T. Malloy, \& J. Fisher (Eds.), The social psychology of intergroup reconciliation (pp. 199-226). New York: Oxford University.

Hughes, J., Campbell, A., Lolliot, S., Hewstone, M., \& Gallagher, T. (2013). Inter-group contact at school and social attitudes: Evidence from Northern Ireland. Oxford Review of Education, 39(6), 761-779.

Hughes, J., \& Loader, R. (2015). 'Plugging the gap': Shared Education and the promotion of community relations through schools in Northern Ireland. British Educational Research Journal, 41(6), 1125-1142. 
Hughes, J., Lolliot, S., Hewstone, M., Schmid, K., \& Carlisle, K. (2012). Sharing classes between separate schools: A mechanism for improving inter-group relations in Northern Ireland? Policy Futures in Education, 10(5), 528-539.

Katz, S., \& Earl, L. (2010). Learning about networked learning communities. School Effectiveness and School Improvement, 21(1), 27-51.

Katz, S., Earl, L., S.B., Jaafar, Elgie, S., Foster, L., Halbert, J., \& Kaser, L. (2008). Learning networks of schools: The key enablers of successful knowledge communities. McGill Journal of Education, 32, 3.

Katz, S., Jafar, S. B., \& Earl, L. M. (2009). Building and connecting learning communities: the power of networks for school improvement. California: Corwin Press.

Knox, C. (2010). Sharing Education Programme: Views from the whiteboard. Jordanstown: University of Ulster.

Kubiak, C., \& Bertram, J. (2010). Facilitating the development of school-based learning networks. Journal of Educational Administration, 48(1), 31-47.

Leonard, M. (2006). Teens and territory in contested spaces: Negotiating sectarian interfaces in Northern Ireland. Children's Geographies, 4(2), 225-238.

Matchett, M. (2004). Education for pluralism in Northern Ireland, presentation to the North of England Education Conference. Coleraine: University of Ulster.

Minority Rights Group. (1994). Education rights and minorities. London: Minority Rights Group.

Moolenaar, N. M., Sleegers, P., Karsten, S., \& Daly, A. (2012). The social fabric of elementary schools: A network typology of social interaction among teachers. Educational Studies, 38(4), 355-371.

Morrissey, M., \& Gaffikin, F. (2006). Planning for peace in contested space. International Journal of Urban and Regional Research, 30(4), 873-893.

Muijs, D., West, M., \& Ainscow, M. (2010). Why network? Theoretical perspectives on networking. School Effectiveness and School Improvement, 21(1), 5-26.

Northern Ireland Assembly Education Committee. (2014a). Inquiry into Shared and Integrated Education. Belfast: NI Assembly http://www.niassembly.gov.uk/assembly-business/committees/ education/calls-for-evidence/inquiry-into-sharedintegrated-education/

Northern Assembly. (2014b). Private member's business: Shared Education, official report Monday 17th February. Belfast: NI Assembly. http://www.niassembly.gov.uk/assembly-business/official-report/ reports-13-14/17-February-2014/\#4

Northern Ireland Assembly. (2010). Private member's business: Integrated and Shared Education. Official report, Tuesday 23 November 2010 volume 58, no 2. Belfast: NI Assembly. http://archive. niassembly.gov.uk/record/reports2010/101123.pdf

Northern Ireland Executive. (2011). Programme for government 2011-2015. Belfast: Office of the First and Deputy First Minister.

Osborne, R. D., Gallagher, A. M., \& Cormack, R. J. (1993). The funding of Northern Ireland's segregated education system. Administration [Dublin], 40(4), 316-332.

Payes, S. (2015). Shared Education across the wall: An education collaboration in the city of Ramla, Israel. Paper presented at the AER A 2015 annual meeting in a symposium session entitled: Collaboration as an antidote to contested spaces in education: The cases of Northern Ireland, Israel and Los Angeles. AERA annual, conference, Chicago.

Richardson, N. (1990). Religious education as if EMU really mattered. Belfast: Christian Education Movement.

Richardson, N., \& Gallagher, T. (2010). Education for diversity and mutual understanding: The experience of Northern Ireland. Bern, Oxford: Peter Lang.

Roche, R. (2009). Facts, fears and feelings: Investigating sectarianism and segregation post-conflict. In The challenges of peace research as a contribution to peace-building in Northern Ireland, edited by The Community Relations Council, 21-36. Belfast: CRC. http://www.sepni.org/site/

Smith, A., \& Robinson, A. (1992). Education for mutual understanding: Perceptions and policy. Coleraine: University of Ulster.

Smith, A., \& Robinson, A. (1996). EMU: The initial statutory years. Coleraine: University of Ulster.

Standing Advisory Commission on Human Rights (SACHR). (1987). Twelfth annual report. London: HMSO (HC 151).

Standing Advisory Commission on Human Rights (SACHR). (1990). Fifteenth annual report. London: HMSO (HC 459).

Wenger, E. (1998). Communities of practice. Oxford: OU Press.

Wenger, E. (2000). Communities of practice and social learning systems. Organization, 7(2), $225-246$.

Woods, P. A., Levacic, R., Evans, J., Castle, F., Glatter, R., \& Cooper, D. (2006). Diversity and collaboration? Diversity pathfinders evaluation (DfES report no. 826). London: DfES. 